\author{
St udia Philosophic a \\ Wr a t i s l a vi e n s i a \\ vol. XIV, fasc. 1 (2019) \\ DOI: $10.19195 / 1895-8001.14 .1 .2$
}

\author{
CALEB BERNACCHIO \\ ORCID: 0000-0002-1732-2458 \\ IESE Business School
}

\title{
Alasdair MacIntyre as an Aristotelian Economic Sociologist: Reading After Virtue with Dependent Rational Animals*
}

\begin{abstract}
Alasdair MacIntyre's After Virtue: A Study in Moral Theory presents a complex argument that spans numerous academic disciplines and combines empirical and theoretical analyses. Its radical conclusion has inspired activists and social critics from all sides of the ideological spectrum. Critics and commentators have questioned MacIntyre's critique of modern moral philosophy and the plausibility of the concluding prescription, concerning the need to create new forms of community. But it has less often been asked in what sense the book presents a unified perspective. In other words, how do the premises of MacIntyre's argument, presented and defended throughout the text, warrant the conclusion? In this article, I partially formalize the main argument of After Virtue, discussing the grounds for each premise, and explaining how they ground the book's radical conclusion. In doing this, I argue that economic sociology, specifically Karl Polanyi's theory of the modern market economy, plays a large role in supporting MacIntyre's claims. After presenting the main argument of the text, I draw upon the social theory elaborated in Dependent Rational Animals: Why Human Beings Need the Virtues, specifically its theory of the relationship between vulnerability, dependence, and virtuous networks of giving and receiving, while briefly noting recent sociological criticisms of Polanyi, to argue that we have reason to be skeptical of MacIntyre's empirical claims concerning the vicious character of modern social structures in After Virtue.
\end{abstract}

Keywords: virtues, vulnerability, economic sociology

* This paper was first given as a lecture at the Pontifical University of the Holy Cross (PUSC) in Rome. I would like to thank Professor Marco D'Avenia for inviting me to give this lecture and Fr. Bob Gahl and other members of the philosophy faculty for helpful criticism. I would also like to thank Ron Beadle and Kelvin Knight for reading a draft of an earlier version of this paper.

Studia Philosophica Wratislaviensia 14, 2019 z. 1,

(C) for this edition by CNS 


\begin{abstract}
"What I also came to recognize was that my conception of human beings as virtuous or vicious needed not only a metaphysical, but also a biological grounding, although not an especially Aristotelian one. This I provided a good deal later in Dependent Rational Animals, where I argued that the moral significance of the animality of human beings, of rational animals, can only be understood if our kinship to some species of not yet rational animals, including dolphins, is recognized. And in the same book I was also able to give a better account of the content of the virtues by identifying what I called the virtues of acknowledged dependence. In so doing I drew on Aquinas's discussion of misericordia, a discussion in which Aquinas is more at odds with Aristotle than he himself realized."
\end{abstract}

\title{
Introduction
}

Readers of After Virtue: A Study in Moral Theory are insufficiently surprised by the conclusion of the book. How does one move from the incoherence of contemporary moral discourse and the shortcomings of analytic moral philosophy to the claim that what "matters at this stage is the construction of local forms of community within which civility and the intellectual and moral life can be sustained through the new dark ages which are already upon us," communities that in some sense stand opposed to the state and the liberal institutional order? ${ }^{2}$ Among MacIntyre's readers, two types are especially noteworthy. The first type largely accepts MacIntyre's critique of modern moral philosophy but severs this critique from MacIntyre's social theory. ${ }^{3}$ In doing this, readers of this type gladly replace the ethical texts of David Hume, Immanuel Kant, and John Stuart Mill with those of Aristotle and Aquinas, but avoid the radical implications concerning the need to build new forms of community that MacIntyre draws from these premises.

In contrast, the second type of readerhas already rejected modernity, typically as a result of some combination of religious or political commitments, and lauds After Virtue for its conclusion while never fully appreciating the central argument of the text. ${ }^{4}$ For this type of reader, the premises of MacIntyre's argument in After Virtue have no force, since such readers have already accepted the radical conclusion (or something near enough). What these two types of readersshare, is a lack of interest in the force of the argument of After Virtue. ${ }^{5}$ But we can only really

${ }^{1}$ A. MacIntyre, After Virtue: A Study in Moral Theory, Notre Dame 2007, p. xi.

2 Ibid., p. 263.

${ }^{3}$ For an example, see R. Miller, "Waiting for St Vladimir: An Admirer of Alasdair MacIntyre's Moral Philosophy Rejects his Political Economy," First Things (February 2011), https://www.firstthings.com/article/2011/02/waiting-for-st-vladimir (accessed: 21.08.2018).

${ }^{4}$ For a prominent example, see R. Dreher, The Benedict Option: A Strategy for Christians in a Post-Christian Nation, New York 2016.

${ }^{5}$ This division is obviously not exhaustive. After Virtue has also found many perceptive readers but these two types of readers are influential and increasingly vocal. 
understand MacIntyre's radical conclusion insofar as we have properly understood the argument leading to it.

In the rest of this paper, I outline the primary argument of After Virtue, identifying four key premises that lead to the radical conclusion noted above. After introducing the argument, I explain the rationale that MacIntyre provides for each premise, before raising questions about the plausibility of the third premise of the argument, MacIntyre's claim that social structures giving expression to a teleological or functional notion of human nature have been marginalized in modernity. For this purpose, I briefly recount recent criticisms of Karl Polanyi's account of the contrast between embedded pre-modern economies and largely disembedded modern market economies, an account that serves as basis for MacIntyre's historical claims in After Virtue, and argue that Dependent Rational Animals: Why Human Beings Need the Virtues, provides further reasons for scepticism concerning After Virtue's claims about the marginalization of virtuous social structures in modernity. Dependent Rational Animals offers an account of the fundamental, but often unacknowledged, social relationships that are partially constitutive of human flourishing, what MacIntyre calls "networks of giving and receiving." Read in the light of Dependent Rational Animals, After Virtue's conclusion is at once more mundane and more radical, for we are lead to realize that the greatest threat to the virtues within modernity is the failure to acknowledge dependence.

\section{The Logical Structure of After Virtue}

The primary argument of After Virtue can be formalized as follows:

a) only teleological ethical theories avoid incoherence;

b) teleological theories presuppose functional notions of human nature;

c) functional notions of human nature must be specified socially rather than metaphysically;

d) the social structures presupposed by a socially specified functional notion of human nature are non-existent;

e) therefore it is necessary to recreate forms of community embodying these social structures in order to be practically rational.

Each premise of this argument could be expanded since each represents the conclusion of a complex set of further arguments, but this formulation simplifies the main argument of the text such that the key results of earlier chapters can be seen as contributing to the radical conclusion, concerning the need to create new forms of community. This formulation also helps to show how normative and empirical claims combine to warrant the conclusion. Specifically, premises (a) and (b) are meta-ethical claims concerning fundamental questions in moral philosophy, while (c) embodies both metaphysical and meta-ethical claims. By contrast, premise (d) is an empirical claim that is closely related to a range of debates within sociology concerning the extent in which the market economy is embedded within thicker social, political, and cultural norms. Finally, by casting the argument in this form, the nature of the conclusion is more evident. Rather than a contingent factor that 
merely contributes to moral education, though it does so contribute, community must be understood as giving expression to a conception of human nature that underwrites the practical activity of its members.

\section{Philosophical Premises}

The first three premises of MacIntyre's argument give expression to a number of highly disputed meta-ethical claims. But the breadth of MacIntyre's claims, the combination of technical philosophical argument and historical hermeneutical interpretation is one reason that After Virtue is both compelling and challenging.

\section{Premise (a)}

As I have noted, MacIntyre does not explicitly formalize the argument of After Virtue but doing so allows one to better understand the unity of the text. The first premise of the argument is as follows: only teleological ethical theories avoid incoherence.

The arguments behind (a) comprise much of the book and are responsible for its iconoclastic character. This premise is stated most clearly in chapter 9, "Nietzsche or Aristotle?" where MacIntyre presents a stark contrast between modern moral philosophy, represented by a collection of non-teleological approaches and Aristotelianism, which is distinguished by its emphasis on the notion of a telos as the basis of moral theory. According to MacIntyre, Nietzsche's terse aphorisms captured the incoherence of modern moral philosophy, which the former presents as the attempt to ground moral norms in the absence of a telos. "Hence the defensibility of the Nietzschean position turns in the end on the answer to the question: was it right in the first place to reject Aristotle?"6 Since non-teleological moral theories fail, the only viable alternative is a broadly Aristotelian, or teleological approach. In this sense, (a) should be understood negatively, as identifying the type of moral theories that is not susceptible to the range of critiques of modern moral philosophy outlined in After Virtue.

MacIntyre does not merely rely upon Nietzsche's criticisms of modern moral philosophy, presenting instead an extended series of arguments in the early portion of the book (as well as at key points later in the text) to support (a). Chapters 3 to 6 provide extended philosophical critiques of both analytic and modern moral philosophy. Without recounting these criticisms here, these chapters present the failure of rationalist approaches, including versions of deontological, utilitarianian, and rights-based approaches. But the power of the arguments in these chapters, arguments against specific philosophical claims, is only apparent when chapters 3 through 6 are read in the light of chapter 2 .

\footnotetext{
${ }^{6}$ A. MacIntyre, After Virtue, p. 117.
} 
In the second chapter, MacIntyre offers a brief phenomenology of contemporary moral discourse, which he describes as in a "state of grave disorder." Read together, chapters 2 through 7 offers a sociology of modern moral philosophy and practice showing the inability of the "Enlightenment Project" to achieve agreement, producing instead an ever-multiplying series of disagreements. The philosophical significance of this fact disagreement is explained in chapter 2, where MacIntyre says, "But if those who claim to be able to formulate principles on which rational moral agents ought to agree cannot secure agreement on the formulation of those principles from their colleagues who share their basic philosophical purpose and method, there is once again prima facie evidence that their project has failed, even before we have examined their particular contentions and conclusions." 8 The fact of disagreement is itself an argument against philosophical approaches that appeal to rational principles supposedly intelligible to all rational agents.

\section{Premise (b)}

If the arguments supporting (a) showed the failure of modern moral philosophy, the arguments supporting (b) serve to bring into greater relief the key characteristics of the alternative teleological approach that MacIntyre endorses. In addition to Kantian and rights-based approaches, MacIntyre had also criticized theories of moral philosophy that claim to explain and justify morality "in terms of [...] the place of the passions and desires in human life." 9 These theories fail either because they can do nothing more than recommend that agents do whatever it is that most satisfies their interests - a recommendation that empties morality of any substantive content - or because they appeal to the something like the notion of sympathy, which MacIntyre describes as a "philosophical fiction" that serves to bridge the gap between self-interest and commitment to unconditional rules, a gap that is "logically-unbridgeable."10

The second premise of the main of argument of the text is: teleological theories presuppose functional notions of human nature. The failure of interest- or desire-based theory explains the need for this second premise. It is not sufficient to appeal to broadly teleological theories that justify moral norms in terms of the agent's interests and/or desires, the appeal must instead be made to a telos that is not arbitrary, representing an expression of the agent's nature. The notion of a functional concept helps to give content to the relevant idea of nature.

A number of points can be noted about MacIntyre's introduction of functional concepts. First, this notion should be initially understood negatively in terms of the arguments in support of (a) noted above. The notion of nature understood as a functional concept that MacIntyre introduces, is precisely the notion that was rejected by modern moral philosophers who sought to justify moral norms in the absence of a telos. MacIntyre contrasts the original "threefold scheme in which hu-

\footnotetext{
${ }^{7}$ Ibid., p. 2.

8 Ibid.

${ }^{9}$ Ibid., p. 49.

10 Ibid.
} 
man-nature-as-it-happens-to-be (human nature in its untutored state) is initially discrepant and discordant with the precepts of ethics and needs to be transformed by the instruction of practical reason and experience into human-nature-as-itcould-be-if-it-realized-its-telos" 11 with the modern two-fold scheme that omits the notion of a telos. The notion of telos in the original scheme was captured by a functional concept that describes the human being in terms of a set of essential activities that give expression to the power and capacities of human nature.

Second, and along similar lines, functional concepts overcome the impasse represented by the arbitrary nature of moral principles, a claim defended in chapter $2,{ }^{12}$ and the arbitrary nature of appeals to existing desires, noted above. Following Arthur Prior, MacIntyre argues that functional concepts allow one to move from factual premises to normative conclusions. "${ }^{13}$ "From such factual premises as 'He gets a better yield for this crop per acre than any farmer in the district', 'He has the most effective programme of soil renewal yet known' and 'His dairy herd wins all the first prizes at the agricultural shows', the evaluative conclusion validly follows that "He is a good farmer." 14 In the case of functional concepts, the criterion identifying objects falling under the concept and the criterion identifying good objects that exemplify the functional concept in an exceptional manner are not independent.

Finally, functional concepts were a key aspect of the conceptual framework that was rejected by proponents of the Enlightenment Project. Thus, insofar as the project of justifying morality in the absence of a notion of a telos fails, and the notion of a telos understood as an expression of the function of human nature avoids the pitfalls of modern moral philosophy, it is a key component of the teleological approach to moral theory. At this point in the argument, MacIntyre is not committed to a specific manner of understanding the notion of a telos or the related notion of human nature understood as a functional concept but he very quickly elaborates upon these notions in the manner that grounds (c), the third premise of the argument.

\section{Premise (c)}

Above, I noted that this premise is both metaphysical and meta-ethical. The metaphysical basis is often explained in terms of MacIntyre's rejection of "Aristotle's metaphysical biology." 15 While MacIntyre does not elaborate upon this point, the gap separating Aristotelian biology from Darwinian approaches is clear-

\footnotetext{
11 Ibid., p. 53.

12 About moral principles MacIntyre says, "The terminus of justification is thus always, on this view, a not further to be justified choice, a choice unguided by criteria. Each individual implicitly or explicitly has to adopt his or her own first principles on the basis of such a choice. The utterance of any universal principle is in the end an expression of the preferences of an individual will and for that will its principles have and can have only such authority as it chooses to confer upon them by adopting them"-After Virtue, pp. 20-21.

13 Ibid., p. 56.

${ }^{14}$ Ibid., p. 58.

15 Ibid.
} 
ly prominent among the rationale behind his rejection of the former. But it would be mistaken to conclude that metaphysical scepticism is the only or even the primary reason behind (c), the claim that functional notions of human nature must be specified socially rather than metaphysically. In another passage, MacIntyre says, "Aristotle thus sets himself the task of giving an account of the good which is at once local and particular - located in and partially defined by the characteristics of the polis - and yet also cosmic and universal," explicitly linking the universal aspects with the notion of a telos articulated in terms of "metaphysical biology."16 According to MacIntyre, Aristotelianism is distinguished by its recognition of the importance of social context in adequately specifying moral norms. This suggests an additional factor behind (c), which could be termed a qualified meta-ethical particularism.

In an earlier paper, titled "What Morality is Not," 17 MacIntyre had criticized Hare's universalism, arguing that morality cannot be defined in terms of universality, and claiming instead that the latter was a substantive moral claim linked with liberalism rather than a meta-ethical requirement. MacIntyre's argument against Hare $^{18}$ revolved around the claim that important moral phenomena, such as particular decisions by individuals in unique situations or supererogatory actions, are not universalizable. In After Virtue, this qualified particularism is extended to historical features of communities, comprised of practices, institutions, and traditions. As such, (c) expresses the claim that the "aims and goals" comprising the human beings' "specific telos" must be articulated in terms of particular features of the communities within which such goals are achieved. What type of communities does MacIntyre have in mind? In a long passage that is worth quoting at length, MacIntyre explains:

In many pre-modern, traditional societies it is through his or her membership in a variety of social groups that the individual identifies himself or herself and is identified by others. I am brother, cousin and grandson, member of this household, that village, this tribe. These are not characteristics that belong to human beings accidentally, to be stripped away in order to discover "the real me". They are part of my substance, defining partially at least and sometimes wholly my obligations and my duties. Individuals inherit a particular space within an interlocking set of social relationships; lacking that space, they are nobody, or at best a stranger or an outcast. To know oneself as such a social person is however not to occupy a static and fixed position. It is to find oneself placed at a certain point on a journey with set goals; to move through life is to make progress - or to fail to make progress - toward a given end. ${ }^{19}$

In this type of community, persons define themselves in terms of their membership in the community and understand themselves primarily in terms of their role in achieving the shared end of the community. Insofar as members identify with the end of the community, norms and virtues associated with fulfilling communal roles are perfectly intelligible in terms of their contribution toward the achievement of the shared communal end.

\footnotetext{
16 Ibid., p. 48.

17 A. MacIntyre, "What Morality is Not," Philosophy 32 (1957), pp. 325-335.

18 R.M. Hare, The Language of Morals, Oxford 1951.

19 A. MacIntyre, After Virtue, pp. 33-34, italics added.
} 
MacIntyre's account of pre-modern communities, though somewhat idealized is by no means artificial. In similar terms, Pierre Bourdieu describes the pre-capitalist communities he researched in Algeria as follows:

[Personal authority] can only be lastingly maintained through actions whose conformity to the values recognized by the group is a practical reaffirmation of that authority. It follows that in such a system, the "great" are those who can least afford to take liberties with the official norms, and that the price to be paid for their outstanding value is outstanding conformity to the values of the group. [I]n pre-capitalist societies [...] [t]he system is such that the dominant agents have a vested interest in virtue; they can accumulate political power only by paying a personal price, and not simply by redistributing their goods and money; they must have the "virtues" of their power because the only basis of their power is "virtue." 20

Bourdieu reiterates the close connection between individual achievement and communal standards. Individual success is largely a matter of upholding communal values, or in Aristotelian terms, the achievement of common goods.

MacIntyre's use of the term "substance" should not be lost on readers since one aim of After Virtue is to defend the claim that human identity is to a large degree historically defined. In terms of the main argument of the text, (c) can be understood as the claim that the aims and goals giving expression to human nature must be articulated socially in terms of the communal structures whereby individuals achieve their end by contributing to the shared end of the community. Together the first three premises of the main argument entail the claim that insofar as communities exist where individuals can achieve their own essential ends by contributing to the shared end of the community, morality can be vindicated and practical incoherence, of the type surveyed in chapter 2 of After Virtue, can be avoided. This leads to the empirical premise (d) underwriting the conclusion of the text.

\section{Economic Sociology in After Virtue}

The fourth and final premise of After Virtue is, in some ways, more straightforward than the previous premises, although the rationale behind (d) is not clearly stated within the text itself, a point noted by MacIntyre himself in a later response to critics. It can be stated as follows: the social structures presupposed by a socially specified functional notion of human nature are non-existent. MacIntyre provides argumentation for this claim at a number of places within the text, most prominently in chapter 3 . There he contrasts the pre-modern forms of communal life, structured in terms of complementary roles with, what is called, "bureaucratic individualism," ${ }^{21}$ where shared moral standards are lacking and individuals seek to achieve their goals while manipulating others, each of whom is similarly attempting to achieve individualistic goals while manipulating others to their own advantage. MacIntyre describes this in terms of the notion of "emotivism," now understood as an empirical claim, involving the "obliteration of any genuine dis-

\footnotetext{
${ }^{20}$ P. Bourdieu, Outline of a Theory of Practice, Cambridge 1977, pp. 193-194.

${ }^{21}$ A. MacIntyre, After Virtue, p. 35.
} 
tinction between manipulative and non-manipulative social relations." 22 At first glance, this may seem like merely an extraordinarily pessimistic interpretation of contemporary social structures, i.e., states, markets, and formal organizations. But this fails to fully grasp MacIntyre's claim which can only be understood in terms of Karl Polanyi's account ${ }^{23}$ of the disembedding process characteristic of the rise of capitalism and the development of modern market economies. ${ }^{24}$

Polanyi's influence is evident at one key point in After Virtue. In chapter 16, MacIntyre says,

One of the key moments in the creation of modernity occurs when production moves outside the household. So long as productive work occurs within the structure of households, it is easy and right to understand that work as part of the sustaining of the community of the household and of those wider forms of community which the household in turn sustains. As, and to the extent that, work moves outside the household and is put to the service of impersonal capital, the realm of work tends to become separated from everything but the service of biological survival and the reproduction of the labor force, on the one hand, and that of institutionalized acquisitiveness, on the other. ${ }^{25}$

This is a tacit but clear reference to Polanyi's discussion of "the principle of householding," which he explains as "the principle [...] of producing and storing for the satisfaction of the wants of the members of the group," ${ }^{26}$ rather than primarily for the individual. According to Polanyi, the Industrial Revolution began a process whereby markets became disembedded, separating from the communal contexts where individuals goals were linked with communal goals. Polanyi presents a complex narrative that links new technologies and changing regulations with the growth of markets and the destruction of traditional communities. But for MacIntyre's argument, and especially for premise (d), what is essential is that social relations before and after the Industrial Revolution are radically different.

According to Polanyi, before the rise of capitalism, persons lived and worked within communities where individual roles were complementary and individual success was defined in terms of the success of the community. In this sense, markets were embedded within thick communal norms. But afterwards, individuals lost this connection to such communities, often because they ceased to exist. Instead, the individuals came to increasingly define their own goals individualistically, in terms of economic or financial success, in part because new modes of production altered social relations and in part because the communal context of

${ }^{22}$ Ibid., p. 23.

${ }^{23}$ See P. McMylor, Alasdair MacIntyre: Critic of Modernity, London 1994 for an extended treatment of Polanyi's influence on MacIntyre.

${ }^{24}$ In a review of After Virtue, MacIntyre's former colleague, Marx Wartofsky had argued that MacIntyre failed to explain why modern individualist social structures were adopted since the philosophical history sketched in the text was not adequately related to an account of social history. In response to Wartofsky, MacIntyre acknowledged this weakness in the text but noted that his account in After Virtue relies upon Karl Polanyi's The Great Transformation (A. MacIntyre, "After Virtue and Marxism: A Response to Wartofsky," Inquiry 27 (1984), p. 253; M. Wartofsky, "Virtue Lost or Understanding MacIntyre," Inquiry 27 (1984), pp. 235-250).

25 A. MacIntyre, After Virtue, p. 227.

${ }^{26}$ K. Polanyi, The Great Transformation: The Political and Economic Origins of Our Time, Boston 2001, p. 56 . 
production ceased to exist. Read in the light of Polanyi's account, MacIntyre's claims concerning the nature of modern social structures express a particular account of the genesis of modern society in terms of the breakdown of pre-modern communities after the expansion of markets.

This account of the rise of modernity, linked with the previous premises, grounds the radical conclusion of After Virtue, concerning the need to create new forms of community. Stated together, MacIntyre argues that the only viable form of moral theory - the only approach capable of avoiding incoherence - is a teleological theory of morality where the fundamental goals of individuals, expressing the goals characteristic of human nature, are specified in terms of the communal structures that link individual achievement with the wellbeing of the community; and further that these communities, though once prominent, are now largely non-existent, as a result of the rise of capitalism, and because of this efforts must be made to reestablish the communal structure within which individuals are able to become practically rational.

\section{Questioning the Argument}

While some philosophers have questioned (a), arguing that universalist moral theories can be vindicated, ${ }^{27}$ and others have rejected (b) arguing that morality can be understood as an expression of underlying non-rational commitments, I will raise questions briefly about MacIntyre's third (c) premise and more extensively about his fourth premise (d), in both cases drawing support from MacIntyre's later work.

\section{In Defense of Tradition}

First, as noted above, (c) relies on both the limitations of Aristotle's pre-Darwinian biology and MacIntyre's defence a qualified meta-ethical particularism. One objection to (c) draws upon MacIntyre's later work on traditions, especially Three Rival Versions of Moral Enquiry: Encyclopaedia, Genealogy and Tradition, ${ }^{28}$ arguing that traditions of inquiry provide substantial ethical resources capable of informing practical reason, such that one may avoid the incoherence identified in chapter 1 of After Virtue insofar as one is able to draw upon a well-ordered moral tradition, even within the context of modernity, and even without questioning the adequacy of MacIntyre's understanding of modernity (without questioning (d)). One could go further than this, noting the importance of the Thomist tradition, and its identification of a theoretical account of human nature that can inform practical reasoning, as MacIntyre has argued on a number of occasions, including most recently in Ethics in the Conflicts of Modernity. ${ }^{29}$ But this response is not

${ }^{27}$ See, for example, O. O'Neill, "Kant after Virtue," Inquiry 26 (1983), pp. 387-405; J. Habermas, Justification and Application, Cambridge 1993.

28 A. MacIntyre, Three Rival Versions of Enquiry: Encyclopaedia, Genealogy and Tradition, Notre Dame 1991.

${ }^{29}$ A. MacIntyre, Ethics in the Conflicts of Modernity, Cambridge 2016. 
entirely satisfactory since it remains unclear how and to what extent traditions of inquiry can inform practical reasoning in the context of widespread moral breakdown.

\section{Questioning MacIntyre's Sociology}

Instead of focusing on criticisms of (c), in the remainder of this paper I will outline a number of related objections to (d), MacIntyre's empirical premise concerning the marginalization of social structures giving expression to human nature in modernity, drawing especially upon Dependent Rational Animals. This later text is explicitly presented as a revision of After Virtue, and, I will argue, it represents a revision of (d) such that we have reason to be more optimistic concerning the extent to which existing social structures give expression to rather than distort human nature.

Dependent Rational Animals does not offer alternative empirical evidence concerning contemporary social structures but it does offer a social theory that suggests that some of the more radical claims about the marginalization of social structures conducive to the exercise of the virtues, social structures that give expression to human nature, are implausible. Accordingly, I will briefly outline the social theory of Dependent Rational Animals, before noting more recent perspectives in economic sociology that provide additional reasons for scepticism concerning (d).

MacIntyre describes Dependent Rational Animals as "a correction of some of my earlier enquiries, stating further, "I now judge that I was in error in supposing an ethics independent of biology to be possible [...] One such failure, of immense importance on its own account, is the nature and extent of human vulnerability and disability. And by not reckoning adequately with this central feature of human life I had necessarily failed to notice some other important aspects of the part that the virtues play in human life." ${ }^{\prime 30}$ For the purpose of this objection, there are a number of noteworthy points in this passage. First, MacIntyre's account hinges on the claim that vulnerability and dependence are ubiquitous, a fundamental aspect of the human condition, facts that have been ignored by much of the philosophical tradition. ${ }^{31}$ MacIntyre describes this as a manifestation of the unwillingness to acknowledge dependence.

Second, dependence typically takes a very distinct form; it is exhibited in non-calculating relationships wherein participants engage in forms of care in order to meet the needs of others. Such relationships extend from "conception to natural

${ }^{30}$ A. MacIntyre, Dependent Rational Animals: Why Human Beings Need the Virtues, Notre Dame 1999, pp. ix-x.

${ }^{31}$ It might be surprising to suggest that MacIntyre had ignored these relationships in After Virtue, but on the opening page of Dependent Rational Animals, he suggests that in the entire philosophical tradition from "Plato to Moore and since" there are "only passing references to human vulnerability and affliction and the connections between them and our dependence on others." MacIntyre argues that by recognizing the ubiquity of vulnerability within human life, we will also become aware of the extent to which we are dependent upon others - in need of forms of care that enable us to achieve flourishing. 
death."32 The relationship between mother and child is one prominent example but MacIntyre describes Aristotelian friendship as a paradigmatic example, ${ }^{33}$ though he also indicates that this form of care is likely to exist between strangers, who come to the aid of persons in urgent need. MacIntyre says that the "network of giving and receiving relationships necessarily extends beyond family and immediate local community," 34 encompassing workplaces and relationships between citizens within the context of the modern state. ${ }^{35}$ These relationships are fundamental and ubiquitous because they enable persons to cope with vulnerability - threats to human flourishing.

Finally, networks of giving and receiving are sustained by a distinct set of virtues, what MacIntyre calls the virtues of acknowledged dependence. ${ }^{36}$ Prominent among these virtues are mercy, beneficence, and just generosity - a virtue that sustains reciprocal patterns of giving and receiving - but MacIntyre indicates that he does not intend to provide an exhaustive list. These virtues are linked because they direct agents to treat various manifestations of the needs of others as reasons for action.

How does this account relate to the argument of After Virtue and specifically to (d), MacIntyre's empirical premise concerning the marginalization of social structures conducive to the virtues - the destruction of forms of community that give expression to human nature - in modernity? The social theory outlined in Dependent Rational Animals suggests that is exceedingly implausible to conclude from the facts of overt disagreement, of the type surveyed in chapter 2 of After Virtue, that there are no shared standards concerning the virtues and human flourishing. Instead, such disagreement is likely to mask a substantial amount of agreement stemming from shared experiences of vulnerability and care, experiences resulting in large part from human animality.

MacIntyre suggests this possibility, saying, "What extended comparative study of the varying characteristics of communities that embody networks of giving and receiving may teach us is how better to identify what relationships of the relevant kinds of giving and receiving already exist in our own local community and how perhaps to greater extent than we have realized there is already a degree of shared recognition of the common good." "37 Networks of giving and receiving, like the traditional communities discussed in After Virtue, function by linking individual human flourishing with the common good of the network. They do this because virtuous acts of care, directed towards the needs of participants, create and sustain

\footnotetext{
32 Ibid. p. 9.

33 Ibid., p. 160: "How the virtues enable us to view ourselves and others and our relationship to others, as actual or potential members of some network of giving and receiving, is perhaps best captured by Aristotle's discussion in Book IX of the Nicomachean Ethics (1166a1-1166b29), where he argues that, insofar as we are good, we stand to ourselves, just as we stand to our friends, and vice versa."

${ }^{34}$ Ibid., p. 83.

35 A. MacIntyre, "Danish Ethical Demands and French Common Goods: Two Moral Philosophies," European Journal of Philosophy 18 (2010), pp. 1-16.

${ }^{36}$ Ibid., p. 10.

37 A. MacIntyre, Dependent Rational Animals, p. 144.
} 
the relationships, by which the agent herself is enabled to cope with vulnerability in order to achieve flourishing.

Commenting on After Virtue, Charles Taylor argues that even within modernity "we are far more 'Aristotelian' than we allow." ${ }^{38}$ Dependent Rational Animals suggests that he is correct, that by participating in networks of giving and receiving, we already live and act within forms of community that give expression to human nature by linking individual well-being to the common good of the community. These claims are supported by more recent criticisms of Polanyi, criticisms that are relevant to properly evaluating the claims of After Virtue.

Mark Granovetter, a leading economic sociologist, has argued that Polanyi's account of modern markets, specifically the tendency to sharply contrast pre-modern and modern forms of economic organization, treating the former as embedded within social norms, and the latter as substantially disembedded, fails to account for the extent to which economic relationships are continuously re-embedded within thicker social norms. ${ }^{39}$ While I cannot survey this research here, Granovetter's work has spurred many others who have uncovered similar forms of embedded economic relationships within modern organizations and markets. ${ }^{40}$ Read in the light of Dependent Rational Animals, more recent perspectives on embeddedness within economic sociology, suggests that this evidence is a manifestation of the ubiquity of vulnerability and dependence, and as such, that these relationships are ethically salient, shaped by the virtues and contributing to the flourishing of participants. ${ }^{41}$ But the prominence of theoretical and empirical research within sociology challenging Polanyi's claims concerning the nature of economic relationships after the Industrial Revolution raise questions about the extent to which his claims support the argument of After Virtue.

Reconsidering (d) in the light of Dependent Rational Animals and more recent perspectives in economic sociology suggests that this premise should be modified as follows:

(d) the social structures presupposed by a socially specified functional notion of human nature are often unacknowledged, both intentionally and unintentionally.

Like Aristotle's great-souled man who "is ashamed to receive benefits" and is "forgetful of what he has received" 42 we often fail to acknowledge dependence, and in doing so, fail to appreciate the extent to which we are already part of

38 C. Taylor, "Justice after Virtue," [in:] After MacIntyre, J. Horton, S. Mendus (eds.), Notre Dame 1995, pp. 16-43.

39 See M. Granovetter, "Economic Action and Social Structure: The Problem of Embeddedness," American Journal of Sociology 91 (1985), pp. 481-510; M. Granovetter, Society and Economy: Framework and Principles, Cambridge 2017.

40 See, for example, B. Uzzi, "Social Structure and Competition in Interfirm Networks: The Paradox of Embeddedness," Administrative Science Quarterly 42 (1997), pp. 35-67.

41 For an extended argument concerning the relevance of Dependent Rational Animals for understanding embeddedness in contemporary organizations see C. Bernacchio, "Networks of Giving and Receiving in Contemporary Organizations: Dependent Rational Animals and MacIntyrean Business Ethics," Business Ethics Quarterly, forthcoming.

42 A. MacIntyre, Dependent Rational Animals, p. 127, quoting Aristotle, Nicomachean Ethics, 1124b9-10. 
communities that give expression to human nature in terms of shared virtues and a conception of the common good. Incorporating (d) the conclusion to be drawn from the argument After Virtue read in the light of Dependent Rational Animals is as follows:

(e) therefore it is necessary to acknowledge the full extent of our dependence upon others and to engage in virtuous forms of care that sustains the networks of giving and receiving that we already participate in order to be practically rational.

This modified conclusion is at once more radical and more mundane than the conclusion of After Virtue. It is more mundane because it points us toward ordinary social relationships that often involve very ordinary forms of care, relationships that we already participate in. But it is more radical because it highlights the ethical salience of such ordinary relationships and suggests that acknowledging our dependence on others may be the most important form of resistance that we can engage in.

\section{Conclusion}

Combining theoretical and empirical analyses, After Virtue presents a complex argument that spans numerous academic disciplines. Its radical conclusion has inspired activists and social critics from all sides of the ideological spectrum. Commentators have questioned MacIntyre's criticisms of modern moral philosophy and the plausibility of its radical concluding prescription but it has less often been asked in what sense the premises defended throughout the text warrant the conclusion. In this article, I partially formalize the main argument of After Virtue, discussing the grounds for each premise, and explaining how they warrant the book's radical conclusion. After presenting the main argument of the text, I draw upon the social theory elaborated in Dependent Rational Animals, specifically its account of the relationship between vulnerability, dependence, and virtuous networks of giving and receiving to argue that we have reason to be sceptical of MacIntyre's empirical claims concerning the vicious character of modern social structures in After Virtue. In the light of Dependent Rational Animals, a more mundane but more radical conclusion is warranted, to be practically rational we must first acknowledge the full extent of our dependence upon others whose care enables us to flourish.

\section{Bibliography}

Bernacchio C., "Networks of Giving and Receiving in an Organizational Context:

Dependent Rational Animals and MacIntyrean Business Ethics," Business Ethics Quarterly 28 (2018), pp. 377-400, doi:10.1017/beq.2018.1.

Bourdieu P., Outline of a Theory of Practice, Cambridge 1977.

Dreher R., The Benedict Option: A Strategy for Christians in a Post-Christian Nation, New York 2016. 
Granovetter, "Economic Action and Social Structure: The Problem of Embeddedness," American Journal of Sociology 91 (1985), pp. 481-510.

Granovetter M., Society and Economy: Framework and Principles, Cambridge 2017.

Habermas J., Justification and Application, Cambridge 1993.

Hare R.M., The Language of Morals, Oxford 1951.

MacIntyre A., "What Morality is Not," Philosophy 32 (1957), pp. 325-335.

MacIntyre A., "After Virtue and Marxism: A Response to Wartofsky," Inquiry 27 (1984), pp. 251-254.

MacIntyre A., Three Rival Versions of Enquiry: Encyclopaedia, Genealogy and Tradition, Notre Dame 1991.

MacIntyre A., Dependent Rational Animals: Why Human Beings Need the Virtues, Notre Dame 1999.

MacIntyre A., "After Virtue: A Study in Moral Theory", 3rd ed., Notre Dame 2007.

MacIntyre A., "Danish Ethical Demands and French Common Goods: Two Moral Philosophies," European Journal of Philosophy 18 (2010), pp. 1-16.

MacIntyre A., Ethics in the Conflicts of Modernity, Cambridge 2016.

McMylor P., Alasdair MacIntyre: Critic of Modernity, London 1994.

Miller R., "Waiting for St Vladimir: An Admirer of Alasdair MacIntyre's Moral Philosophy Rejects his Political Economy," First Things (February 2011), https:/ www. firstthings.com/article/2011/02/waiting-for-st-vladimir (accessed: 21.08.2018).

O’Neill O., "Kant after Virtue," Inquiry 26 (1983), pp. 387-405.

Polanyi K., The Great Transformation: The Political and Economic Origins of Our Time, Boston 2001.

Taylor C., "Justice after Virtue," [in:] After MacIntyre, J. Horton, S. Mendus (eds.), Notre Dame 1995, pp. 16-43.

Uzzi B., "Social Structure and Competition in Interfirm Networks: The Paradox of Embeddedness," Administrative Science Quarterly 42 (1997), pp. 35-67.

Wartofsky M., "Virtue Lost or Understanding MacIntyre," Inquiry 27 (1984), pp. 235-250. 